\title{
Study on the Constitutional Free Press Guarantee
}

\author{
Zhao Lina \\ Public Security Fire Force College \\ PSFFC \\ Kunming, China \\ 770596290@qq.com
}

\begin{abstract}
The freedom of the press plays an important role in safeguarding citizens' right to know and public opinion supervision. The present study is intended to study how to protect the press freedom of citizens in the constitution. This paper outlines some of the necessity of press freedom in the constitution by discussing the laws of the west. These results support the ideas that the independence of press freedom in the constitution is necessary and Constitutional judicialization must be promoted.
\end{abstract}

Keywords-freedom of press; constitutional; fundamental rights; guarantee

\section{INTRODUCTION}

In 1904, Pulitzer wrote for the North American Review in an article: "our republic will live with the media. The maintenance of social morality, needs to have the courage to distinguish between right and wrong, trained with regularity, intelligent journalists justice appeared, and have the ability and justice, with the spirit of the people in the media. The power to shape the future of the Republic, in the hands of future journalists." Thus, with the development of society, the freedom of the press plays an important role in meeting the right of citizens to know and guaranteeing the realization of citizen's right of supervision by public opinion. As a fundamental political right, most of the modern democratic countries put the freedom of the press into the category of rights protected by the constitution. From the bill of rights to the French Declaration of human rights and the first amendment to the constitution of the United States, freedom of the press has been recognized in the constitution of most countries in the world. However, in our country there are still some shortcomings in the protection of the freedom of the press, this paper analysis of these problems based on the basis of the constitutional protection of the freedom of the press on the experience of western countries, put forward their own views.

\section{THE NECESSity of CONSTITUtionAl GUARANTEE OF FREE} PRESS

\section{A. Free press is the inherent requirement of constitutional spirit.}

The purpose of the constitutional government is not only to establish a system to guarantee the operation of state power, what's more important is that it must reflect the power of owner's wishes. So it will not produce power even to deviate from the right of the owner of the facade. So, to achieve the above purpose, as the highest law, the limitation of national power of the constitution can be divided mainly into three aspects: firstly, the provisions of the constitution of state power belong to the people, authorization and entrust the power of government comes from the people; secondly, the constitution of power operation provides a moral foundation, namely power operation is to promote civil rights and public interests; thirdly, the Constitution limits the operation of administrative power. It is in this sense that the spirit of constitutional government demands to strengthen the restriction and supervision of power. However, the social news supervision is an indispensable form of public opinion supervision, and the freedom of the press is the internal logic premise for the realization of the news supervision. Therefore, from the connotation of constitutional government, the freedom of the press is the only way to realize democracy and the inherent requirement of the constitutional spirit.

\section{B. The freedom of the press has become an important part of the basic rights.}

The question of whether the freedom of press can be put into the scope of constitutional protection depends on whether the press freedom belongs to the category of basic rights. The content of rights is rich and various, which constitutes a huge system. In this system of rights, the rights of those who are of great importance and essential belong to the people, the socalled basic rights. Basic rights are not static, but vary with the evolution of social history. Marx once pointed out: "human rights are not natural, but formed in history". With the rapid rise of the news media, the freedom of the press has become an important right of citizens' freedom of expression, the right to know, the right to supervise and the Democratic rights. In other words, without freedom of press and publication, all other freedoms will become a bubble." Just as some scholars have pointed out, "although the speech expression and freedom of the press as civil rights that has clearly identified and in tort law can be remedied, it is essential for every citizen in the modern society and the whole society. Only with this freedom, is it likely to create a real democracy and the rule of law society, people can express their own ideas, and government officials may have the supervision of public opinion, and people's right to know is likely to be met." In this sense, the freedom of the press is not only the basic freedom of information and the right to know, but also the protection of freedom of expression and supervision. On the one hand, the freedom of the press is the proper meaning of freedom of expression; on the other hand, the news media has the right of 
freedom of the press or the community legal premise and basis of public opinion, if there is no constitutional, or legal affirmation of the principle ,or freedom of press supervision of public opinion, all is but a mere formality. Therefore, the freedom of the press should be stipulated in the constitution as the basic rights.

\section{THE STATUS QUO OF CHINA'S CONSTITUTIONAL PROTECTION OF PRESS FREE}

Democratic countries attach great importance to the protection of the importance of freedom of the press, and it gradually come up with several mature systems. However, in China, we only put it in the thirty-fifth provisions of "constitution": " citizens of People's Republic of China have the freedom of speech, publication, assembly, association, procession and demonstration." These provisions are too simple and the lack of protection of freedom of the press, the main problems of which are as below.

\section{A. The Absence of Protection of Free Press in the text of the Constitution.}

The freedom of the press is based on the freedom of press and freedom of speech. In the gradual evolution of the process, it derived a number of new values, functions and content, the nature of the development and change. In the world, many countries have made specific provisions on freedom of the press. For example, the British constitution is not directly on the freedom of the press, but in the freedom of the press as follows: "English publishing all free, large in general, there are two characteristics: the first purpose: not subject to inspection... Second mesh: not subject to special court trials..." In France, the sixteenth article of the declaration of human rights provides the protection of the freedom of speech and freedom of the press. Although the United States is the bourgeois revolution carried out smoothly, the freedom of the press in the United States the bourgeois regime still caused intense controversy, until 1789, the 10 amendment to the constitution, the first of which clearly states: "Congress shall make no law on the following matters: the establishment of religion or prohibiting the freedom of religious belief; people are deprived of their freedom of speech or press; right of the people peaceably to assemble and to petition the government for the right". So far, the freedom of the press has been recognized and protected by the constitution of the United states.

From the freedom of speech and the press of the security and supervision, we can see that ,derived to guarantee the freedom of the press mode led directly to the definition of the scope of the free right purpose, procedures, limits and standards are not clear. In order to adapt to the realistic social system and structure perspective, there are two problems: one is not in harmony with the status of freedom of the press in the democratic construction of rule of law; the other is that freedom of the press is an independent right to freedom of speech, independent of the value reason and tool reason, if only radiated into the freedom of speech, it is not conducive to the comprehensive protection of the freedom of the press, which is not conducive to the full play of the function of the system.

\section{B. The Lack of Constitutional Safeguard System.}

Constitutional protection is a general term for the establishment of the system and principle of safeguarding the authority of the Constitution and ensuring the implementation of the constitution. The main contents are: the clear provisions of the supreme legal effect, expressly modify special procedures of the constitution in order to ensure the steady implementation of the constitution, to establish constitutional authority to interpret the constitution, constitutional review and processing cases, to ensure the full implementation of the constitution and the content of the constitutional supervision system of a country. In addition, each country must also provide other aspects of measures to protect the implementation of the constitution." In our country, the system of the protection of constitution has not been established, and the judicial system of the Constitution and the system of unconstitutional review are still under discussion. This is not conducive to the protection of freedom of the press.

\section{HOW TO IMPROVE THE CONSTITUTIONAL PROTECTION OF FREEDOM OF THE PRESS}

\section{A. Put the Freedom of the Press into the Constitution - apart from the Provisions of Freedom of Expression.}

Press freedom contains value independently of the freedom of words and speech, which makes two differences on the subject of rights. Content and structure, rights and properties has been varying. Coupled with the freedom of the press in a democratic society in the important position and role, it should be incorporated into the constitutional protection. At the legislative level, first of all, we should make clearly the meaning of freedom of the press. It is defined as: through the media performance out of the freedom of speech and publication, which is focused on news and related works in a series of activities of the freedom of news media, it is recognized in law or circumstances, timely and objectively, such as collection, interviews, writing, transmission, publication, comment, printing, publishing news and other works related to this autonomy state. Secondly, through the amendment of the constitution, the freedom of the press becomes the basic rights, together with the freedom of speech. This is because, on the one hand, although the freedom of the press is independent of the freedom of speech, publication of the function and value of freedom, they are mutual connection, mutual penetration. Therefore, the two parallel rules help to understand and protect it; on the other hand, to play free press system function is to achieve the overall the effect of the exercise of rights through its content, and the press freedom will be feasible only when it is based on the protection of specific rights.

\section{B. Promoting the Judicial Process of Constitution.}

If the press freedom can be put clearly into the constitution, the freedom of the press advocated by citizens will definitely be guaranteed. But also we should recognize that it is just a beginning for us to enjoy the rights of free press, the key is the system of construction and how to put it into practice. If the Constitution can't be put into the judicial process, the legal basis for the trial of the case, in the case of the right to freedom 
of the press, there will inevitably be unable to follow the situation. This not only can't guarantee the citizens enjoy the freedom of press in the constitution, but also lose the authority and dignity of the constitution. It is not difficult to sum up this point from the cases in recent years in our country. Therefore, it has become our urgent needs to improve the constitutional protection system.

\section{CONCLUSIONS}

With the development of the times, the freedom of the press plays an important role in meeting the satisfaction of civil rights to know and ensuring the realization of the right of supervision by public opinion. However, in our country, the freedom of the press is not clearly stipulated in the constitution. So we should put the freedom of the Press into the Constitution apart from the Provisions of Freedom of Expression, and promote the judicial process of constitution.

\section{REFERENCES}

[1] Xu Chongde, Hu Jinguang, Li Yuanqi, and Ren Jin, "Constitution,” Renmin University of China press,2008,pp.201.(In Chinese)

[2] Marx, "The complete works of Marx," people's Publishing House,1956.(In Chinese)

[3] Zhang Ximing,“Tension and restriction,” Chongqing: Chongqing publishing house, 2002.(In Chinese)

[4] Ni Na, "Comments on the freedom of the press in the West, " Journal of the University of journalism, 2003.(In Chinese)

[5] Li Ying, "On the dual nature of freedom of the press," Journal of Luoyang University,2005.(In Chinese)

[6] Zhang Haiting,"On the protection and restriction of freedom of press in China," news and legal system,2001.(In Chinese)

[7] Yang Quanming,"The theory of constitutional protection,” Sichuan: Sichuan University press, 1990.(In Chinese)

[8] Ding Zhengmin,“On the legal protection of freedom of the press,” Nanjing: Nanjing University of Aeronautics \& Astronautics, 2005.(In Chinese)

[9] Liu Xiaoshu, “The constitutional rights of freedom of the press”, Beijing: China University of Political Science and Law, 2004.(In Chinese) 